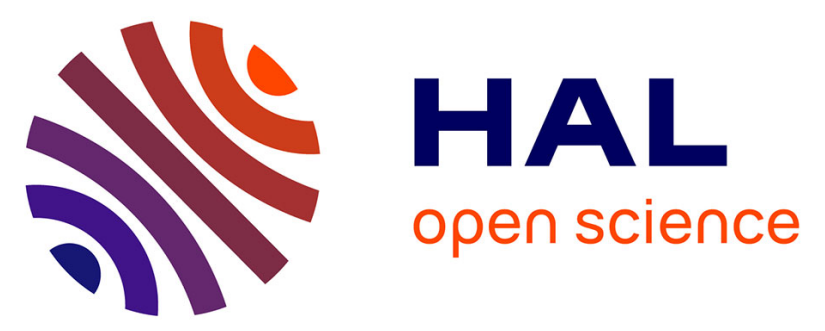

\title{
Computed tomography, histological and ultrasonic measurements of adolescent scoliotic rib hump geometrical and material properties
}

J.-Ph. Berteau, Martine Pithioux, H. Follet, C. Guivier-Curien, Ph

Lasaygues, P. Chabrand

\section{To cite this version:}

J.-Ph. Berteau, Martine Pithioux, H. Follet, C. Guivier-Curien, Ph Lasaygues, et al.. Computed tomography, histological and ultrasonic measurements of adolescent scoliotic rib hump geometrical and material properties. Journal of Biomechanics, 2012, 45 (14), pp.2467-2471. 10.1016/j.jbiomech.2012.07.002 . hal-01183696

\section{HAL Id: hal-01183696 \\ https://hal.science/hal-01183696}

Submitted on 6 Nov 2019

HAL is a multi-disciplinary open access archive for the deposit and dissemination of scientific research documents, whether they are published or not. The documents may come from teaching and research institutions in France or abroad, or from public or private research centers.
L'archive ouverte pluridisciplinaire HAL, est destinée au dépôt et à la diffusion de documents scientifiques de niveau recherche, publiés ou non, émanant des établissements d'enseignement et de recherche français ou étrangers, des laboratoires publics ou privés. 


\title{
Computed tomography, histological and ultrasonic measurements of adolescent scoliotic rib hump geometrical and material properties
}

\author{
J.-Ph. Berteau ${ }^{\text {a,c }}$, M. Pithioux ${ }^{\mathrm{a}, *}$, H. Follet ${ }^{\mathrm{b}}$, C. Guivier-Curien $^{\mathrm{a}}$, Ph. Lasaygues ${ }^{\mathrm{c}}$, P. Chabrand ${ }^{\mathrm{a}}$ \\ ${ }^{a}$ Institute of Movement Sciences ISM - UMR 6233 CNRS/Aix-Marseille University, 163 Avenue de Luminy, Case Postale 910, 13288 Marseille Cedex 09, France \\ ${ }^{\mathrm{b}}$ Pathophysiology, Diagnosis and Treatments of Bone Diseases INSERM UMR1033 University of Lyon, 7-11 Rue G. Paradin, 69372 Lyon Cedex 08, France \\ ${ }^{\mathrm{c}}$ Laboratory of Mechanics and Acoustics LMA UPR 7051 CNRS, 31 Chemin J. Aiguier, 13402 Marseille Cedex 20, France
}

\section{A R T I C L E I N F O}

\section{Article history:}

Accepted 9 July 2012

\section{Keywords:}

Scoliosis

Cortical bone

Geometrical properties

Ribs

\begin{abstract}
A B S T R A C T
In Adolescent Idiopathic Scoliosis (AIS), numerical models can enhance orthopaedic or surgical treatments and provide reliable insights into the mechanism of progression. Computational methods require knowledge of relevant parameters, such as the specific geometrical or material properties of the AIS rib, about which there is currently a lack of information. The aim of our study was to determine the geometrical and material properties (Young's modulus $[E]$ and Poisson's ratio $[v]$ ) for AIS rib bones. Twelve ribs extracted during gibbectomy on 15 and 17 year old girls were tested using computed tomography $(\mathrm{CT})$ scanner, histology and ultrasonic scanner. The mean porosity ( \pm standard deviation $(\mathrm{SD}))$ is $1.35( \pm 0.52) \%$ and the mean $( \pm \mathrm{SD})$ bone mineral density is $2188( \pm 19) \mathrm{mmHA} / \mathrm{cc}$. The cortical part of the AIS rib hump is found to be thicker than physiological values in the literature. To mimic the rib hump for an AIS girl, our results suggest that ribs should be modeled as hollow circular cylinders with a $10.40( \pm 1.02) \mathrm{mm}$ external radius and $7.56 \mathrm{~mm}( \pm 0.75)$ internal radius, and material properties with a mean $E$ of $14.9 \mathrm{GPa}( \pm 2.6)$ and a mean $v$ of $0.26( \pm 0.08)$.
\end{abstract}

\section{Introduction}

Adolescent Idiopathic Scoliosis (AIS) is a common deformity of the spine inducing skeletal and geometrical modifications (Panagitis et al., 2000). To understand the etiopathogeny and to optimize treatment, computational models are used (Stokes and Laible, 1990; Clin et al., 2010; Berteau et al., 2011), but require relevant geometrical and material properties. Currently, these are taken from non-scoliotic adults (Descrimes et al., 1995) although AIS is a pediatric pathology leading to geometrical modifications and an overall reduction of bone mineral density (BMD) (Cheng et al., 2000; Lee et al., 2005; Szalay et al., 2008).

While the impact of AIS on vertebra geometrical modifications and mineral distribution has frequently been investigated (Stokes and Aronsson, 2001; Perie et al., 2001; Adam and Askin, 2008), there is a lack of references concerning scoliotic rib hump characteristics. In this study, geometrical properties and BMD were obtained by computed tomography (CT) scanner, porosity and bone organization by histology, and material properties ( $E$, Young's modulus; $v$, Poisson's ratio) by ultrasonic (US) measurements.

\footnotetext{
* Corresponding author. Tel.: +33 491266 177; fax: +33491411691.

E-mail address: martine.pithioux@univ-amu.fr (M. Pithioux).
}

\section{Materials and methods}

\subsection{Samples}

Using a Marseille hospital population (Table 1), we studied AIS ribs (pathological flat bone) from two Caucasian 15 and 17-year-old girls (right single thoracic curve, Cobb angle higher than $40^{\circ}$ ). Gibbectomy was done after more than 3 years of orthopaedic brace wearing. A total of 12 ribs (six from each patient), designated as F-age-R-ribNumber, were extracted from the proximal level (Fig. 1) and stored at $-20^{\circ} \mathrm{C}$.

\subsection{Geometrical properties}

Each extracted rib was scanned entirely and separately with a clinical scanner (Siemens AG, Erlangen, Germany; scans were $0.6 \mathrm{~mm}$ apart with a square pixel resolution of $0.6 \mathrm{~mm}$ ) (CT-Scan1 in Fig. 2). For each of them, the threshold value to separate out the cortical and the trabecular bone was obtained by comparing only the first CT-Scan slide with the first histological slide (c.f. Section 2.3). A custom software code (developed with MATLAB, The MathWorks, Natick, USA) provided cortical thickness (four locations: superior (SUP), inferior (INF), anterior (ANT), posterior (POST), Fig. 2), cortical area (CA) and total area (TA). Knowing these areas, each rib is consequently considered as a hollow circular cylinder which leads to a mean cortical thickness (Table 2) based on the difference in its external and internal radii.

\subsection{Histological properties}

As abnormal cortical porosity may play a role in US measurements (Grondin et al., 2012), an optical microscope was used to calculate cortical bone porosity (PoCB) from digitized images (Z1 Zeiss, Germany, $12 \mathrm{MHz}-36$ bit; ImageJ http:// 
rsb.info.nih.gov/ij). Samples were embedded via standard process (Chavassieux et al., 1997), to obtain $8 \mu \mathrm{m}$ thick sections stained with Golden trichrome and the complete process of binarization, thresholding and pore circling was performed twice to assess reproducibility.

Table 1

Exclusion criterion list for the studied population.

\begin{tabular}{|c|c|}
\hline Criterion & Exclusion \\
\hline Ethnos & African, Hispanic, Asiatic \\
\hline Sex & Genetic disorder \\
\hline Clinical pathology & $\begin{array}{l}\text { Metabolic disease, renal dysfunction, diabetes, } \\
\text { asthma }\end{array}$ \\
\hline $\begin{array}{l}\text { Chronic or frequent use of } \\
\text { medicine }\end{array}$ & $\begin{array}{l}\text { Corticoid, inhaled steroid antiepileptic drug, } \\
\text { growth hormones }\end{array}$ \\
\hline Beddriden & Bed rest time before surgery \\
\hline Puberty & Unascertainable \\
\hline Calcium daily amount & Less than $1000 \mathrm{mg}$ or special diet \\
\hline
\end{tabular}

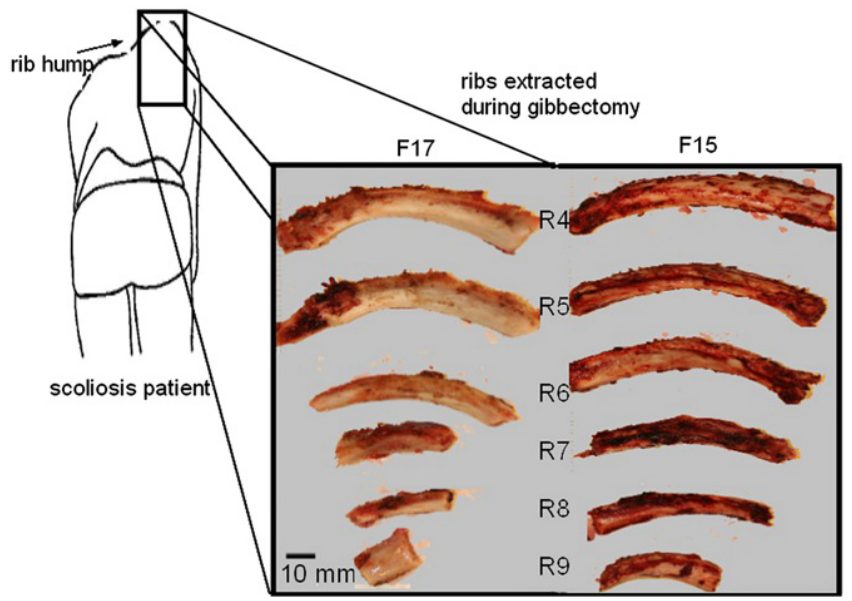

Fig. 1. Rib hump in posterior anterior view (PA) and 12 ribs (R4-R9) extracted during gibbectomy, six from each patient (15-year-old girl (F15) and 17-year-old girl (F17).

\subsection{Material properties}

After a second cutting in each extracted rib, smaller parallelepipedic samples (15-35 mm long, 10-20 mm wide, 2-3.5 mm thick) were obtained when possible (F15: 2 samples available in R4, 2 in R5, 2 in R6, 0 in R7-R8-R9 and F17: 0 in R4, 2 in R5, 1 in R6, 4 in R7, 2 in R8, 0 in R9). A second CT-Scan (CT-Scan2 in Fig. 2) provided Hounsfield units (HU). The CT-Scan2 calibration performed by Mimics software (Materialise NV) using different concentrations of hydroxyapatite (200, $800,1000,1250$, and $1750 \mathrm{mgHA} / \mathrm{cc}$ ), converted HU into BMD (mgHA/cc) through

$\mathrm{BMD}=0.8565 \mathrm{HU}+224.23, \quad R^{2}=0.991$

US measurements were performed in a water tank, previously vacuumdegassed, on the same samples. Two focused broadband transducers at $7 \mathrm{MHz}$ (5 mm diameter, focal length $30 \mathrm{~mm}$; Imasonic, Besançon, France) operated through each sample in transmit-receiver mode on a mechanical support allowing translations in 3D. For each sample, longitudinal (LV) and transversal (TV) velocity were obtained as done by Pithioux et al. (2002). Using the Archimedes principle, a micrometric balance (610 GX0.001G voyager) measured bone mass density, $\rho$ (each parameter was assessed by performing tests in triplicate). $E$ and $v$ in the transversal direction (Ashman et al., 1984; Pithioux et al., 2002; Dong and Guo, 2004) were provided through the following equations:

$E=\rho \times \frac{T V^{2} \times\left(3 L V^{2}-4 T V^{2}\right)}{\left(L V^{2}-T V^{2}\right)}$

$v=\frac{L V^{2}-2 T V^{2}}{L V^{2}-T V^{2}}$

\section{Results}

All results are presented as mean value ( \pm standard deviation $( \pm \mathrm{SD}))$.

\subsection{Geometrical properties}

After CT-Scan1, 10 sets of scans were suitable for geometrical analysis and according to the rib length, they were composed of 56-136 scans (sets from each R9 were excluded because of too few useful scans (under 10)). The threshold value to extract the cortical part of the rib was roughly $60 \%$ of the maximum grey level of the CT-Scan1 image. The minimum CA (105.92 $\left.( \pm 11.83) \mathrm{mm}^{2}, \mathrm{~F} 17 \mathrm{R} 8\right)$ and maximum $\left(214.73( \pm 47.30) \mathrm{mm}^{2}\right.$,

\section{CT-Scan 1: all along the extracted rib Slides each $0.6 \mathrm{~mm}$}
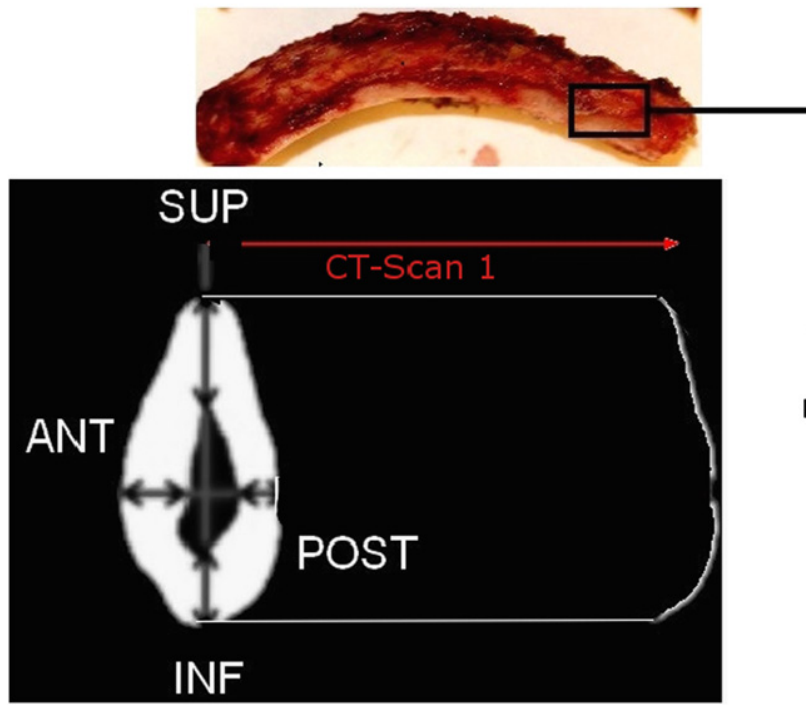

CT-Scan2: on small parallelepipedic samples

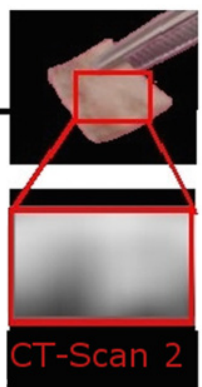

Region of interest

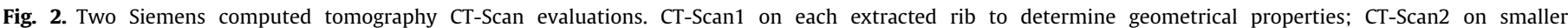
parallelepipedic samples to determine BMD. 
Table 2

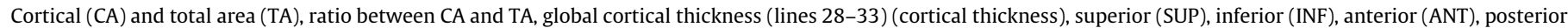

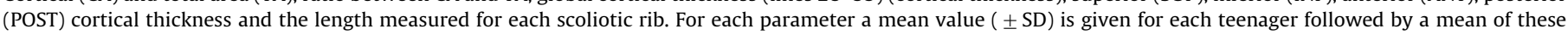
mean values $( \pm$ SD) (lines 30-36).

\begin{tabular}{|c|c|c|c|c|c|c|c|c|c|}
\hline & $\mathrm{CA}\left(\mathrm{mm}^{2}\right)$ & $\mathrm{TA}\left(\mathrm{mm}^{2}\right)$ & Ratio CA/TA & $\begin{array}{l}\text { Cortical } \\
\text { thickness (mm) }\end{array}$ & $\begin{array}{l}\text { Superior [SUP] } \\
(\mathrm{mm})\end{array}$ & $\begin{array}{l}\text { Inferior [INF] } \\
(\mathrm{mm})\end{array}$ & $\begin{array}{l}\text { Anterior [ANT] } \\
(\mathrm{mm})\end{array}$ & $\begin{array}{l}\text { Posterior [POST] } \\
(\mathrm{mm})\end{array}$ & Length (mm) \\
\hline F15R4 & $214: 73( \pm 47: 30)$ & $425: 12( \pm 54: 03)$ & $0: 50( \pm 0: 04)$ & $3: 43( \pm 0: 58)$ & $3: 00( \pm 0: 81)$ & $4: 75( \pm 2: 49)$ & $3: 32( \pm 0: 66)$ & $3: 79( \pm 1: 06)$ & 78.0 \\
\hline F15R5 & $207: 80( \pm 38: 89)$ & $439: 00( \pm 54: 76)$ & $0: 47( \pm 0: 03)$ & $3: 23( \pm 0: 45)$ & $3: 15( \pm 0: 86)$ & $4: 45( \pm 1: 68)$ & $3: 03( \pm 0: 67)$ & $3: 04( \pm 1: 06)$ & 81.6 \\
\hline F15R6 & $184: 71( \pm 12: 74)$ & $384: 29( \pm 29: 72)$ & $0: 48( \pm 0: 02)$ & $3: 09( \pm 0: 14)$ & $2: 15( \pm 0: 59)$ & $3: 05( \pm 1: 59)$ & $4: 13( \pm 0: 71)$ & $2: 60( \pm 0: 60)$ & 61.2 \\
\hline F15R7 & $184: 10( \pm 10: 39)$ & $419: 90( \pm 03: 45)$ & $0: 44( \pm 0: 02)$ & $2: 90( \pm 0: 18)$ & $2: 94( \pm 0: 88)$ & $3: 45( \pm 1: 73)$ & $2: 72( \pm 0: 47)$ & $3: 80( \pm 1: 04)$ & 36.0 \\
\hline F15R8 & $41: 56( \pm 04: 68)$ & $312: 00( \pm 13: 23)$ & $0: 50( \pm 0: 04)$ & $2: 60( \pm 0: 13)$ & $3: 90( \pm 2: 58)$ & $2: 62( \pm 0: 60)$ & $2: 46( \pm 0: 48)$ & $3: 30( \pm 0: 57)$ & 33.6 \\
\hline Mean & $186: 58( \pm 25: 61)$ & $396: 06( \pm 45: 74)$ & $0: 47( \pm 0: 02)$ & $3: 05( \pm 0: 28)$ & $3: 02( \pm 0: 56)$ & $3: 66( \pm 0: 81)$ & $3: 13( \pm 0: 57)$ & $3: 30( \pm 0: 45)$ & $58: 08( \pm 22: 62)$ \\
\hline F17R4 & $155: 10( \pm 39: 74)$ & $309: 50( \pm 39: 74)$ & $0: 50( \pm 0: 04)$ & $2: 90( \pm 0: 51)$ & $3: 09( \pm 1: 00)$ & $4: 74( \pm 2: 45)$ & $3: 36( \pm 0: 70)$ & $3: 73( \pm 1: 10)$ & 79.8 \\
\hline F17R5 & $153: 27( \pm 38: 35)$ & $323: 70( \pm 38: 35)$ & $0: 47( \pm 0: 03)$ & $2: 77( \pm 0: 37)$ & $3: 32( \pm 1: 05)$ & $4: 55( \pm 1: 72)$ & $3: 10( \pm 0: 87)$ & $3: 02( \pm 0: 64)$ & 81.6 \\
\hline F17R6 & $140: 84( \pm 22: 91)$ & $290: 28( \pm 22: 91)$ & $0: 49( \pm 0: 02)$ & $2: 72( \pm 0: 11)$ & $3: 04( \pm 0: 59)$ & $3: 82( \pm 1: 58)$ & $4: 10( \pm 0: 76)$ & $2: 66( \pm 0: 79)$ & 61.8 \\
\hline F17R7 & $138: 38( \pm 03: 94)$ & $312: 79( \pm 03: 94)$ & $0: 44( \pm 0: 01)$ & $2: 53( \pm 0: 10)$ & $2: 92( \pm 0: 89)$ & $3: 42( \pm 1: 69)$ & $2: 74( \pm 0: 46)$ & $3: 71( \pm 1: 08)$ & 36.0 \\
\hline F17R8 & $105: 92( \pm 11: 83)$ & $223: 84( \pm 11: 83)$ & $0: 47( \pm 0: 04)$ & $2: 32( \pm 0: 17)$ & $3: 90( \pm 2: 58)$ & $2: 62( \pm 0: 60)$ & $2: 46( \pm 0: 48)$ & $3: 30( \pm 0: 57)$ & 33.6 \\
\hline Mean & $138: 70( \pm 17: 66)$ & $292: 02( \pm 35: 75)$ & $0: 47( \pm 0: 02)$ & $2: 64( \pm 0: 20)$ & $3: 25( \pm 0: 34)$ & $4: 55( \pm 0: 98)$ & $3: 15( \pm 0: 56)$ & $3: 28( \pm 0: 41)$ & $58: 56( \pm 20: 23)$ \\
\hline $\begin{array}{l}\text { Mean of } \\
\text { means }\end{array}$ & $162: 64( \pm 32: 51)$ & $344: 04( \pm 66: 26)$ & $0: 47( \pm 0: 02)$ & $2: 85( \pm 0: 32)$ & $3: 14( \pm 1: 13)$ & $4: 11( \pm 0: 44)$ & $3: 14( \pm 0: 10)$ & $3: 29( \pm 0: 11)$ & $58: 32( \pm 0: 34)$ \\
\hline
\end{tabular}

F15R4) differ by roughly 50\%. Within a rib, the area values are in a similar range (Table 2 ). The ratio (CA/TA) yields a mean value of $0.47( \pm 0.02)$. If the rib is considered as a hollow circular cylinder, the area values lead to a mean cortical thickness of 2.85 $( \pm 0.02) \mathrm{mm}$, to a mean external radius of $10.40( \pm 1.02) \mathrm{mm}$ and to a mean internal radius of $7.56( \pm 0.75) \mathrm{mm}$. The cortical thickness measurements for the four specific locations and their mean values are presented in Table 2, the mean of means is 3.42 $( \pm 0.40) \mathrm{mm}$. Due to variations along the rib the maximum thickness related to F17R4 is: $4.74( \pm 2.45) \mathrm{mm}$ and to F15R4 is: $4.75( \pm 2.49) \mathrm{mm}$, the minimum thickness related to F17R8 is: $2.32( \pm 0.17) \mathrm{mm}$ and F15R6 is: $2.15( \pm 0.59) \mathrm{mm}$. As shown in Table 2 , cortical thicknesses vary as a function of location in the rib cross section.

\subsection{Histological properties}

Tissue morphology of AIS rib cortical bone shows the usual adult cortical bone morphology, which is lamellar with ostenal organization with micro-pores (Fig. 3). Mean PoCB value is 1.35 $( \pm 0.52) \%$ and never exceeds $2.18 \%$.

\subsection{Material properties}

Mean BMD values is $2046( \pm 168) \mathrm{mgHA} / \mathrm{cc}$ for F15 and 2330 $( \pm 202) \mathrm{mgHA} / \mathrm{cc}$ for $\mathrm{F} 17$, the mean of mean values is 2188 $( \pm 19)$ mgHA/cc. Mean $\rho$ is $1.96( \pm 0.73) \mathrm{g} / \mathrm{cc}$ for F15 and 2.37 $( \pm 0.38) \mathrm{g} / \mathrm{cc}$ for F17, the mean of mean values is $2.16( \pm 0.20) \mathrm{g} /$ cc. The LV, TV , E and $v$ values for each rib sample studied here and their mean value are shown in Table 3.

\section{Discussion}

The 12 ribs from two AIS teenage girls show a porosity lower than $2.18 \%$ and a mean BMD of $2188( \pm 19) \mathrm{mgHA} / \mathrm{cc}$. The mean cortical layer is $2.85( \pm 0.32) \mathrm{mm}$ thick with a mean $E$ of 14.9 $( \pm 2.6) \mathrm{GPa}$ and a mean $v$ of $0.26( \pm 0.08)$.

Li et al. (2010) showed that a computational model including variable cortical rib thickness induces better mechanical behavior than a constant thickness model. The values obtained vary along the rib extracted (Table 2) with a maximum standard deviation (SD) of 50\% (F15R4) and a minimum of 20\% (F15R7). Mohr et al. (2007), studying whole physiological ribs, found a maximum of 83\% (R4: $0.6( \pm 0.5) \mathrm{mm}$ ) and a minimum of 28\% (R6 and R7: 1.4

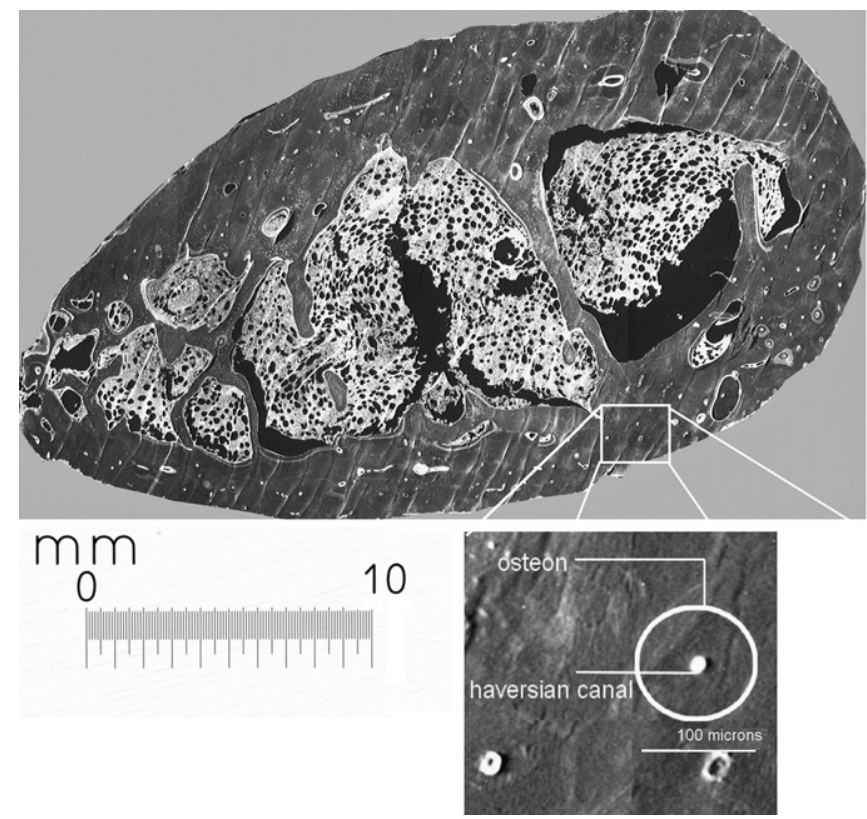

Fig. 3. Grayscale image of $8 \mu \mathrm{m}$ (thickness) histological slide $(5 \times)$ of scoliotic rib (F15R2). Osteon and Harversian canal can be distinguished on the zoom part. Such histological images were used to determine porosity.

$( \pm 0.4) \mathrm{mm})$. Even though our extracted ribs are shorter than a whole rib, the highest SD found here for AIS ribs is in the average range of SD found for physiological bone.

The AIS brace worn by the two patients is known to apply a mean force of $40 \mathrm{~N}$ on the rib hump (Petit et al., 1998). In vivo, DeSouza et al. (2005) and El Haj et al. (1990) pointed out the key role of mechanical stimulation in healing, remodeling and regeneration of bone. Knowing the physiological values for the rib cortical thickness at the proximal level of the whole ribs $(1.25 \mathrm{~mm})$ (Mohr et al., 2007), the brace force could stimulate the bone modeling process and cause a thicker cortical thickness in AIS $(2.85( \pm 0.02) \mathrm{mm})$. Furthermore, the mean of means for the four specific locations is higher than the mean thickness based on the area radii, it can be explained by the fact that SUP and INF are anatomic crests locations. To describe the geometrical parameters of a normal rib at this level, Mohr et al. (2007) used a "bounding box" $11.3 \mathrm{~mm}$ high, $6.9 \mathrm{~mm}$ wide. As a better description of AIS ribs, we suggest a "hollow circular" cylinder with a 
Table 3

Longitudinal (LV) and transversal velocity (TV) obtained from ultrasonic measurements. Young's modulus $(E)$ and Poisson's ratio ( $v$ ) calculated through Eqs. (2) and (3). $-i$ stands for the number of the parallelepipedic sample extracted from the considered rib.

\begin{tabular}{|c|c|c|c|c|c|}
\hline Rib number & Number of samples $(N)$ & $\operatorname{LV}(\mathrm{m} / \mathrm{s})$ & $\mathrm{TV}(\mathrm{m} / \mathrm{s})$ & $E(\mathrm{GPa})$ & $v$ \\
\hline F15R4-1 & 2 & 3934 & 1711 & 14.7 & 0.39 \\
\hline F15R4-2 & & 3029 & 1691 & 12.1 & 0.27 \\
\hline F15R5-1 & 2 & 2425 & 1600 & 10.4 & 0.15 \\
\hline F15R5-2 & & 3336 & 1821 & 16.8 & 0.28 \\
\hline F15R6-1 & 2 & 3501 & 1753 & 14.6 & 0.33 \\
\hline F15R6-2 & & 3530 & 1766 & 15.6 & 0.33 \\
\hline Mean & & $3292( \pm 413)$ & $1724( \pm 75)$ & $14.1(2.3)$ & $0.28(0.08)$ \\
\hline F17R5-1 & 2 & 3184 & 1796 & 15.3 & 0.27 \\
\hline F17R5-2 & & 2527 & 1687 & 10.9 & 0.10 \\
\hline F17R6-1 & 1 & 3511 & 1863 & 17.8 & 0.30 \\
\hline F17R7-1 & 4 & 3287 & 1861 & 16.2 & 0.26 \\
\hline F17R7-2 & & 2773 & 1752 & 11.7 & 0.17 \\
\hline F17R7-3 & & 4248 & 1968 & 19.4 & 0.36 \\
\hline F17R7-4 & & 3094 & 1815 & 15.5 & 0.24 \\
\hline F17R8-1 & 1 & 3628 & 1869 & 17.5 & 0.32 \\
\hline F17R8-2 & & 3264 & 1794 & 14.4 & 0.29 \\
\hline Mean & & $3280( \pm 497)$ & $1823( \pm 80)$ & $15.4(2.8)$ & $0.27(0.08)$ \\
\hline Mean of means & & $3286( \pm 59)$ & $1773( \pm 3)$ & $14.7(0.3)$ & $0.27(0.00)$ \\
\hline
\end{tabular}

$10.40( \pm 1.02) \mathrm{mm}$ external radius and a $7.56( \pm 0.75) \mathrm{mm}$ internal radius, which is still a simplification of the complex geometrical properties of AIS ribs.

Concerning the microscopic anatomy, PoCB of the rib hump is lower than $2.18 \%$ and osteonal orientation is in the direction of rib axis. Both are identical to an adult cortical bone (Qiu et al., 2003), indicating there is no influence of AIS in our samples.

AIS is known to lead to an overall reduction of BMD (Cheng et al., 2000; Lee et al., 2005; Szalay et al., 2008), however these clinical studies focus only on the femur. In vitro values obtained appear high compared to adult values (930-1345 mgHA/cc Wachter et al., 2002; Boivin and Meunier, 2002) and to children tibia values (1014 mgHA/cc Binkley et al., 2005). However, we cannot assert that AIS leads to increase BMD values at the rib hump level without a control group.

In recent computational AIS models (Clin et al., 2010; Berteau et al., 2011), ribs are considered as one entity with mechanical values taken from Descrimes et al. (1995). Far from AIS bone, these values concern adult vertebro-costal unit $(E=5 \mathrm{GPa}$ and $v=0.05$ ). The material properties found here could increase the biofidelity of AIS models. However, one limitation of our focussing solely on the cortical part of the rib hump with an acoustic method, is that samples were scanned in only one direction leading to the assumption of isotropic bone. Our results indicate that LV is in the lower range of normative values for an adult cortical bone $(2700-3800 \mathrm{~m} / \mathrm{s}$ Yoon and Katz, 1976; 3500$3900 \mathrm{~m} / \mathrm{s}$ Bensamoun et al., 2004) and $E$ and $v$ are far removed from typical material property values.

This is a feasibility study and a greater number of subjects (samples) would provide a better statistical analysis. Thereby, it would be possible to provide more relevant parameters (moment of inertia or changes by anatomical level) and to establish a valuable law linking $E$ and BMD as already developed for adult cortical bone (Keyak et al., 1990).

In conclusion, this multi-scale and multi-technique study uses CT-Scan, histology and US measurements of AIS cortical samples. It yields original values on AIS ribs with respect to the current literature and should improve AIS numerical modeling. The cortical part of the AIS rib hump is revealed to be thicker than the physiological adult values found in the literature. To mimic the rib hump of a scoliotic adolescent girl (post peak bone mass), our results suggest that ribs should be modeled as hollow circular cylinders with a $10.40( \pm 1.02) \mathrm{mm}$ external radius, a $7.56 \mathrm{~mm}$
$( \pm 0.75)$ internal radius, and material properties with a mean $E$ of $14.9 \mathrm{GPa}$ and a mean $v$ of 0.26 .

\section{Conflict of interest statement}

There is no conflict of interest.

\section{Acknowledgments}

We are grateful for financial assistance to the ANR project called Biogmid, we thank the Timone's Hospital surgery team and the donors or their legal guardians who gave informed written consent to providing their tissues for investigation, in accordance with the French Code of Public Health (Code de la Santé Publique Français) and approved by the Committee for the Protection of Persons. We thank Marjorie Sweetko for English language revision of the manuscript.

\section{References}

Adam, C.J., Askin, G.N., 2008. Gravity-induced torque and intravertebral rotation in idiopathic scoliosis. Spine 33, E30-E37.

Ashman, R.B., Cowin, S.C., Van Buskirk, W.C., Rice, J.C., 1984. A continuous wave technique for the measurement of the elastic properties of cortical bone. Journal of Biomechanics 17, 349-361.

Bensamoun, S., Ho Ba Tho, M.C., Luu, S., Gherbezza, J.M., de Belleval, J.F., 2004 Spatial distribution of acoustic and elastic properties of human cortical bone. Journal of Biomechanics 37, 503-510.

Berteau, J.P., Pithioux, M., Mesure, S., Bollini, G., Chabrand, P., 2011. Beyond the classic correction system: a numerical nonrigid approach to the scoliosis brace. The Spine Journal 11, 424-431.

Binkley, T., Johnson, J., Vogel, L., Kecskemethy, H., Henderson, R., Specker, B., 2005. Bone measurements by peripheral quantitative computed tomography (PQCT) in children with cerebral palsy. The Journal of Pediatrics 147, 791-796.

Boivin, G., Meunier, P.J., 2002. The degree of mineralization of bone tissue measured by computerized quantitative contact microradiography. Calcified Tissue International 70, 503-511.

Chavassieux, P.M., Arlot, M.E., Reda, C., Wei, L., Yates, A.J., Meunier, P.J., 1997. Histomorphometric assessment of the long-term effects of alendronate on bone quality and remodeling in patients with osteoporosis. Journal of Clinical Investigation 100, 1475-1480.

Cheng, J.C., Cheung, C.S., Sher, A.H., Lee, K.M., Ng, S.W., Guo, X., 2000. Generalized low areal and volumetric bone mineral density in adolescent idiopathic scoliosis. Journal of Bone and Mineral Research 15, 1587-1595.

Clin, J., Aubin, C.E., Parent, S., Sangole, A., Labelle, H., 2010. Comparison of the biomechanical 3D efficiency of different brace designs for the treatment of scoliosis using a finite element model. European Spine Journal 19, 1169-1178. 
Descrimes, J.L., Aubin, C.E., Skalli, W., Zeller, R., Dansereau, J., Lavaste, F., 1995. Modelling of facet joints in a finite element model of the scoliotic spine and thorax: mechanical aspects. Rachis 7, 301-314.

DeSouza, R.L., Matsuura, M., Ckstein, F.E., Rawlinson, S.C.F., Lanyon, L.E., Pitsillides, A.A., 2005. Non-invasive axial loading of mouse tibiae increases cortical bone formation and modifies trabecular organization: a new model to study cortical and cancellous compartments in a single loaded element. Bone 37, 810-818.

Dong, X.N., Guo, E., 2004. The dependence of transversely isotropic elasticity of human femoral cortical bone on porosity. Journal of Biomechanics 37, 1281-1287.

El Haj, A.J., Minter, S.L., Rawlinson, S.C., Suswillo, R., Lanyon, L.E., 1990. Cellular responses to mechanical loading in vitro. Journal of Bone Mineral Research 9, 923-932.

Grondin, J., Grimal, Q., Yamamoto, K., Matsukawa, M., Saied, A., Laugier, P., 2012. Relative contributions of porosity and mineralized matrix properties to the bulk axial ultrasonic wave velocity in human cortical bone. Ultrasonics 52 (4), 467-471.

Keyak, J.H., Meagher, J.M., Skinner, H.B., Mote, C.D.J., 1990. Automated three dimensional finite element modelling of bone: a new method. Journal of Biomedical Engineering 12, 389-397.

Lee, W.T.K., Cheung, C.S.K., Guo, X., Qin, L., Lam, T.P., Ng, B.K.W., Cheng, J.C., 2005 Association of osteopenia with curve severity in adolescent idiopathic scoliosis: a study of 919 girls. Osteoporosis International 16, 1924-1932.

Li, Z., Kindig, M.W., Kerrigan, J.R., Untaroiu, C.D., Subit, D., Crandall, J.R., Kent, R.W. 2010. Rib fractures under anterior-posterior dynamic loads: experimental and finite-element study. Journal of Biomechanics 43, 228-234.

Mohr, M., Abrams, E., Engel, C., Long, W.B., Bottlang, M., 2007. Geometry of human ribs pertinent to orthopedic chest-wall reconstruction. Journal of Biomechanics 40, 1310-1317.
Panagitis, K., Christos, K., Grigoris, P., Soucacos, P.N., 2000. Effects of thoracolumbosacral orthosis on spinal deformities, trunk asymmetry, and frontal lower rib cage in adolescent idiopathic scoliosis. Spine 25, 2064-2071.

Perie, D., Sales De Gauzy, J., Baunin, C., Ho Ba Tho, M.C., 2001. Tomodensitometry measurements for in vivo quantification of mechanical properties of scoliotic vertebrae. Clinical Biomechanics 16, 373-379.

Petit, Y., Aubin, C.E., Dansereau, J., Gignac, D., Joncas, J., de Guise, J.A., Labelle, H., 1998. effect of strap tension on the pressure generated by the boston brace on idiopathic scoliosis patients: a preliminary study. Journal of Biomechanics 31, 175.

Pithioux, M., Lasaygues, P., Chabrand, P., 2002. An alternative ultrasonic method for measuring the elastic properties of cortical bone. Journal of Biomechanics 35, 961-968.

Qiu, S., Fyhrie, D.P., Palnitkar, S., Rao, D.S., 2003. Histomorphometric assessment of haversian canal and osteocyte lacunae in different-sized osteons in human rib. The Anatomical Record, Part A, Discoveries in Molecular, Cellular, and Evolutionary Biology 272, 520-525.

Stokes, I.A., Aronsson, D.D., 2001. Disc and vertebral wedging in patients with progressive scoliosis. Journal of Spinal Disorders and Techniques 14, 317-322.

Stokes, I.A., Laible, J.P., 1990. Three-dimensional osseo-ligamentous model of the thorax representing initiation of scoliosis by asymmetric growth. Journal of Biomechanics 23, 589-595.

Szalay, E.A., Bosch, P., Schwend, R.M., Buggie, B., Tandberg, D., Sherman, F., 2008 Adolescents with idiopathic scoliosis are not osteoporotic. Spine 33, 802-826.

Wachter, N.J., Krischak, G.D., Mentzel, M., Sarkar, M.R., Ebinger, T., Kinzl, L., Claes, L., Augat, P., 2002. Correlation of bone mineral density with strength and microstructural parameters of cortical bone in vitro. Bone 31, 90-95.

Yoon, H.S., Katz, J.L., 1976. Ultrasonic wave propagation in human cortical bone-II. Measurements of elastic properties and microhardness. Journal of Biomechanics 9, 459-464 